\title{
Internal Temperature Prediction of Lithium-ion Cell Using Differential Voltage Technique
}

\author{
Yashraj Tripathy, Andrew McGordon, John Low and James Marco \\ WMG, University of Warwick \\ Coventry, United Kingdom
}

\begin{abstract}
The performance of a Lithium-ion cell is strongly dependent on cell operating temperature. However, the measured temperature is often obtained from thermocouples attached to the surface of the cell. These measurements may not be representative of the internal temperature of the cell especially for lower ambient temperatures and high $\mathrm{C}$-rates. A novel method utilizing differential voltage to predict the internal temperature of a $40 \mathrm{Ah}$ Lithium-ion pouch cell is proposed. The difference between internal and measured external temperatures depends upon the $\mathrm{C}$-rate and ambient temperature. For a continuous-rate discharge, the difference, between surface and measured temperatures, rises at beginning of discharge before peaking in the middle region and reducing towards the end-ofdischarge. The outcome of this study could positively support control strategies within a battery management system (BMS).
\end{abstract}

Keywords-Lithium-ion Cell; Differential Voltage; Effective Resistance; Low Ambient Temperature; High C-rate

\section{INTRODUCTION}

In the midst of growing concerns for the environment and commitment of governments towards reducing emissions, electric vehicles (EVs) are gaining prominence as a potential solution [1]. An important factor in their success is the energy storage system (ESS) being used [2]. An ideal ESS should have high energy and power density, excellent lifetime, and must be reliable for a range of operating conditions (drivecycles, temperatures, etc.) [3]. Among commercially available battery chemistries, Lithium-ion batteries have the highest volumetric and gravimetric energy/power densities [4], and hence have become the top choice for battery-electric vehicles (BEVs).

BEVs based on Lithium-ion batteries show significant loss in driving-range and power-performance at subzero temperatures [5] and particularly at higher C-rates [6]. Reduced performance is attributed to low conductivity of electrolyte, decline in solid-state Lithium diffusivity, high polarization of the graphite anode, and sluggish charge transfer kinetics $[7,8]$. In their study of $2.2 \mathrm{Ah} 18650 \mathrm{Li}$-ion cells, Ji et al. state that electrochemical performance of cells is strongly dependent on the cell operating temperature [8]. However, as cell operating temperature is usually measured via thermocouples attached to the surface of the cell, it may not be representative of electrochemical processes happening inside the cell [9].
Differential voltage (DV) measurements are used to infer stoichiometric alignment of electrodes at equilibrium or closeto-equilibrium conditions to detect capacity-fading [10]. Higher currents are avoided to prevent charge transfer phenomena [11]. As DV represents voltage change per unit capacity discharged $(\mathrm{dV} / \mathrm{dQ})[12,13]$; it indicates cumulative effect of operating conditions [1] (ambient temperature, Crate, SOC, impedance and self-heating) on the cell.

This paper aims to use the DV technique to predict the 'effective resistance' of the cell for different continuous discharge currents at ambient temperatures between -20 and $25{ }^{\circ} \mathrm{C}$, and thus, its internal temperature. Deviation between the internal and measured cell surface temperature is shown to vary directly with discharge current and declining ambient temperature $[14,15]$. These predictions may help improve control strategies within a battery management system (BMS) by improving accuracy of cell temperature estimation.

\section{RESEARCH METHDOLOGY}

\section{A. Experimental Details}

To explore cell behavior, a Lithium-ion cell pouch cell (weighing $0.97 \mathrm{~kg}$ ) with a NMC cathode was tested. The cell was nominally rated at $3.7 \mathrm{~V}$ and $40 \mathrm{Ah}$ capacity. A k-type thermocouple was attached on to the geometric-centre of the main surface of the pouch cell. The cell was placed in a Votsch thermal chamber and was cycled using a Bitrode cellcycler. The cell was tested at four different ambient temperatures: $-20,-10,0$ and $25{ }^{\circ} \mathrm{C}$. Charging is only carried out at $25{ }^{\circ} \mathrm{C}$. The cell is charged at $0.5 \mathrm{C}(20 \mathrm{~A})$ until the voltage reaches $4.2 \mathrm{~V}$. The charge-current is reduced to $0.05 \mathrm{C}$ with voltage held at $4.2 \mathrm{~V}$. The discharge-currents used were $0.1 \mathrm{C}, 0.2 \mathrm{C}, 0.5 \mathrm{C}, 1 \mathrm{C}, 2 \mathrm{C}, 5 \mathrm{C}$ and $8 \mathrm{C}$. The parameters measured directly were cell voltage $(\mathrm{V})$, capacity $(\mathrm{Ah})$, power $(\mathrm{W})$, discharged energy (Wh) and cell surface (measured) temperature $\left({ }^{\circ} \mathrm{C}\right)$. The cut-off voltage for this cell was $2.7 \mathrm{~V}$.

\section{B. Internal Temperature Prediction}

To calculate 'internal temperature' from measured parameters using differential voltage technique the following steps were taken (Fig. 1):

1. The change in voltage $(\Delta \mathrm{V})$ was calculated every time-step. 2. The 'effective resistance', ' $R$ ', is a linear function of $D V$ that is obtained by dividing $\Delta \mathrm{V}$ by the discharge-current. 


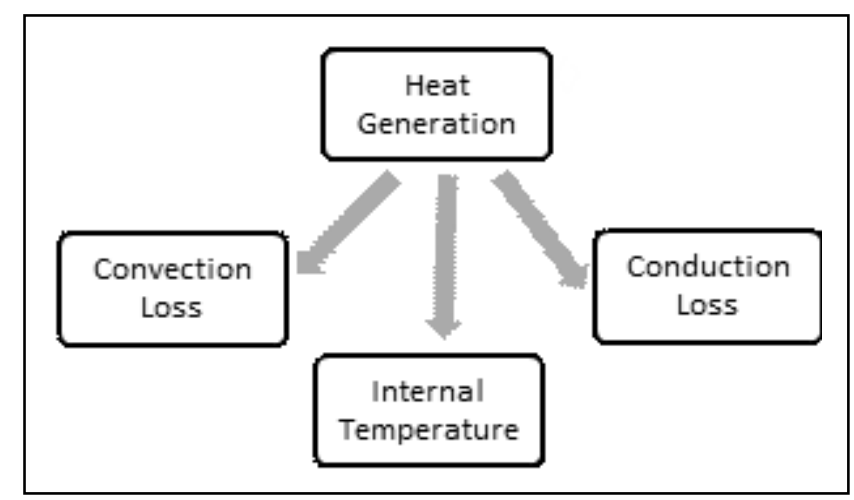

Fig. 1. Simple Heat-Generation Model

3. The heat generated was calculated as $\mathrm{Q}_{\mathrm{gen}}=I^{2} \times R$ every time-step.

4. The heat conducted away from the core of the cell to the surface was calculated as $\mathrm{Q}_{\text {cond }}=(\mathrm{k} \times \mathrm{A} \times \Delta \mathrm{T}) /(\mathrm{L} / 2)$ where ' $\mathrm{k}$ ' is the through-plane thermal conductivity of the cell; ' $A$ ' is the surface area; and ' $\mathrm{L}$ ' is the distance between the core and surface of the cell.

5. Heat transfer due to the convection at the cell surface was calculated as $\mathrm{Q}_{\text {conv }}=\left(\mathrm{h} \times \mathrm{A} \times\left(\mathrm{T}-\mathrm{T}_{\mathrm{amb}}\right)\right)$. Here, ' $\mathrm{h}$ ' is the convective heat-transfer coefficient and $\mathrm{T}_{\mathrm{amb}}$ is the ambient temperature.

6 . From the heat generation equation, $\Delta \mathrm{T}$ was calculated every second: $\Delta T=\left(\mathrm{Q}_{\text {gen }}-\mathrm{Q}_{\text {cond }}-\mathrm{Q}_{\text {conv }}\right) /(m \times C)$. Here, 't' is the timestep (s), ' $\mathrm{m}$ ' is $0.97 \mathrm{~kg}$ and the heat capacity is ' $\mathrm{C}$ '. Q cond at $\mathrm{t}=0 \mathrm{~s}$ is assumed as zero and subsequently $\mathrm{Q}_{\mathrm{cond}}$ is used for the previous time-step.

7. The internal temperature was calculated by integrating the $\Delta T$ at every time-step.

TABLE 1. Cell Parameters for Lithium-ion Pouch Cell

\begin{tabular}{|c|c|}
\hline Parameter & Value \\
\hline Thermal conductivity, $\mathrm{k}$ & $0.48 \mathrm{~W} / \mathrm{m} /{ }^{\circ} \mathrm{C}$ \\
\hline Surface Area, A & $0.10125 \mathrm{~m}^{2}$ \\
\hline Cell Thickness, L & $0.0009 \mathrm{~m}$ \\
\hline Heat Capacity, C & $1243 \mathrm{~J} /{ }^{\circ} \mathrm{C} / \mathrm{kg}$ \\
\hline Convective Coefficient, $\mathrm{h}$ & $10 \mathrm{~W} / \mathrm{m}^{2} /{ }^{\circ} \mathrm{C}$ \\
\hline
\end{tabular}

\section{RESULTS AND DISCUSSION}

In the following sections, results from the continuous discharged experiments are discussed, in terms of discharged capacity and discharged energy; and, the internal temperature of the cell is estimated and is compared to measured cell temperature. Only results for continuous discharge at 1C, 2C and $5 \mathrm{C}$ are discussed for three ambient temperatures $(-10,0$ and $25^{\circ} \mathrm{C}$ ) as they are representative of the tests as a whole.

\section{A. Effect of C-rates and Ambient Temperature on Discharged Capacity and Discharged Energy}

Experimental results confirm that the energy delivered by the cell decreases with increasing C-rate and also with declining ambient temperature (Fig. 3). This is due to faster drop in cellvoltage due to increased cell impedance. This is due to lower ionic conductivity and increased electrolyte resistance [16], higher polarization in the anode [17], slower charge-transfer [18] and insufficient solid-phase diffusion of Lithium [19].

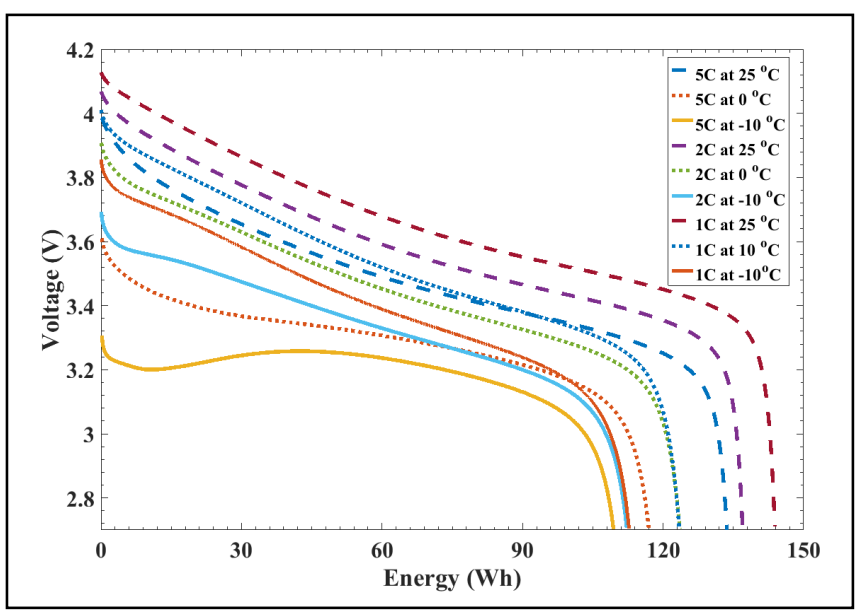

Fig. 2. Cell Voltage Evolution with Discharged Energy at Different Ambient Temperatures and $\mathrm{C}$-rates

The voltage for $5 \mathrm{C}$ discharge at $-10{ }^{\circ} \mathrm{C}$ increases for a considerable period over the course of the discharge-cycle (Fig. $2 \& 3$ ). This is due to self-heating related cell temperature rise. This leads to reduction in electrolyte resistance due to increase in ionic conductivity and salt diffusivity [8]. This leads to higher energy discharged from the cell while compared to an isothermal discharge. However, for $-10{ }^{\circ} \mathrm{C}$ ambient temperature, experimental results show that while discharge capacity for $5 \mathrm{C}$ (Fig. 3) is higher than that for 1C (by $3.6 \%$ ), the discharged energy (Fig. 2) is lower by 2.9 $\%$. Similarly, the discharged capacity for $5 \mathrm{C}$ discharge at $0{ }^{\circ} \mathrm{C}$ is higher than that for $1 \mathrm{C}$ discharge (by $1 \%$ ). But, the corresponding discharged energy is lower by $5.3 \%$.

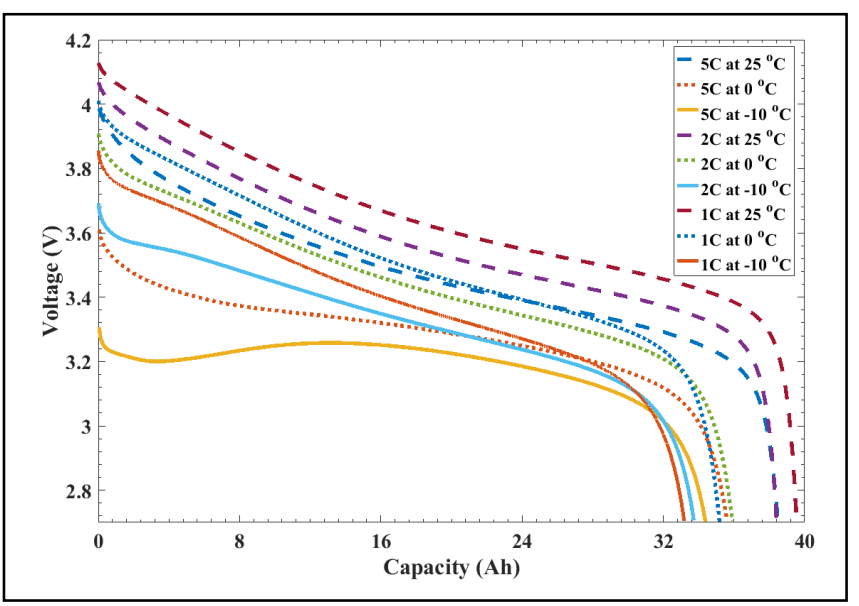

Fig. 3. Cell Voltage Evolution with Discharged Capacity at Various Ambient Temperatures and C-rates

This suggests that capacity-benefits attributed to self-heating may be overstated and that most of the capacity gained is used up to warm up the cell. This is supported by Barai et al. who argue that discharged energy is a better indicator of cell performance than discharged capacity as it takes into account both discharged capacity and voltage [20]. 
B. Effect of C-rates and Ambient Temperature on Internal Temperature Prediction using Differential Voltage

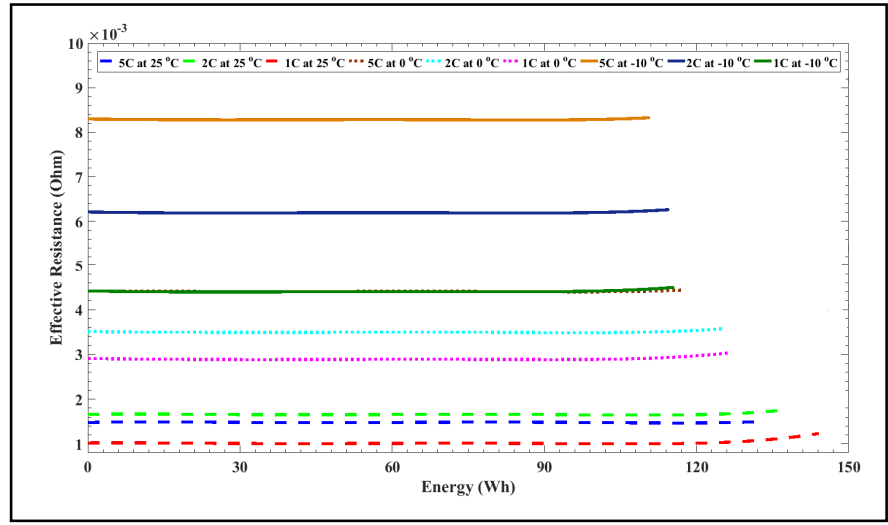

Fig. 4. Effective Resistance versus Discharged Energy at Various Ambient Temperatures and C-rates

It is seen in Fig. 4 that, effective resistance generally increases with declining ambient temperature and increasing C-rate. This suggests that at a point in the discharge cycle, there is a greater change in voltage with energy delivered. The effective resistance is higher at lower ambient temperatures, particularly for higher C-rates, due to lower ionic conductivity, slower charge-transfer, higher electrolyte resistance and slower solidstate diffusion. This agrees with [18] where direct-current resistance is shown to increase with decreasing ambient temperature and increasing C-rate. Further, effective resistance is shown to increase towards the end-of-discharge. It should be noted that, although, there is a great degree of self-heating for $5 \mathrm{C}$ discharge at $-10{ }^{\circ} \mathrm{C}$, its, effective resistance is still the highest. This could be due to lower discharge time for that particular discharge-current. Thus, effective resistance which takes into account the operating conditions can be utilized to predict the internal temperature of the cell.

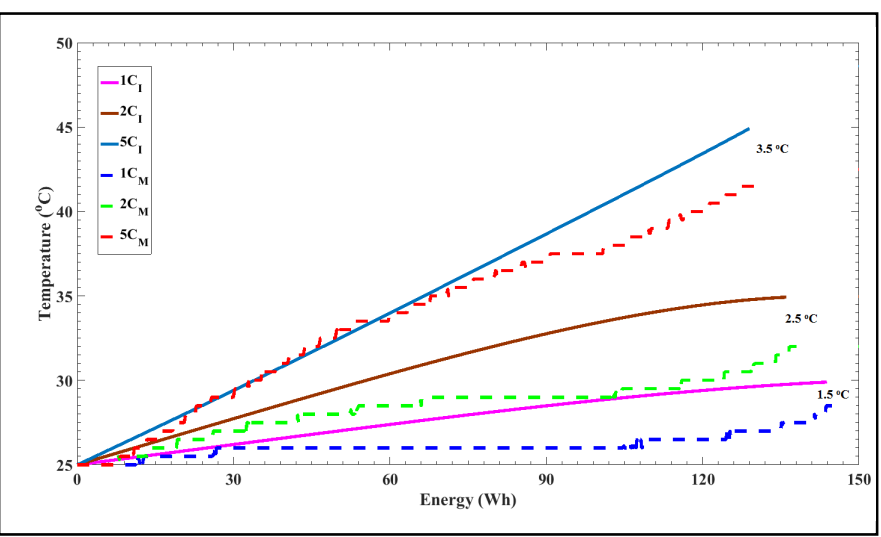

Fig. 5. Comparison between Internal (I) and Measured (M) Temperatures for Various C-rates at $25^{\circ} \mathrm{C}$ Ambient Temperature

It is seen, both measured and internal temperatures increase during discharge (Fig. 5-7). The temperature rise is higher for higher $\mathrm{C}$-rates and lower ambient temperatures due to greater heat generation inside the cell $[8,16]$. The internal temperature of the cell also shows a similar trend albeit with a greater magnitude. In agreement with $[14,15]$, the maximum difference $(\Delta \mathrm{T})$ between the internal and measured temperatures over a discharge cycle is proportional to the corresponding C-rate.

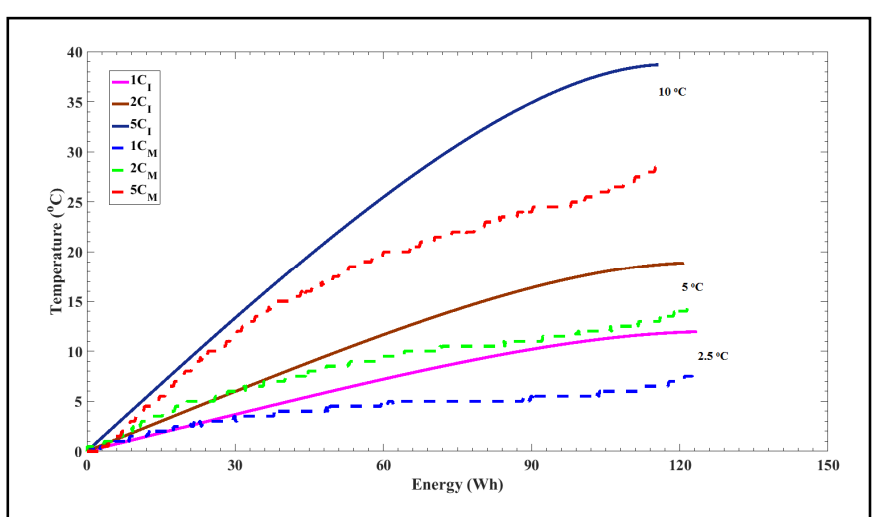

Fig. 6. Comparison between Internal (I) and Measured (M) Temperatures for Various C-rates at $0{ }^{\circ} \mathrm{C}$ Ambient Temperature

It is also seen in Fig. $6 \& 7$, that this difference increases as the ambient temperature is reduced. For a $50 \mathrm{Ah}$, NMC pouch cell, Veth et al. compared the temperature difference across the cell surface ( $\Delta$ Tsurface) using PT-100 electrical sensors for up $6 \mathrm{C}$ and, 0 and $25^{\circ} \mathrm{C}$, ambient temperatures [14]. The maximum $\Delta \mathrm{T}_{\text {surface }}$ was $3{ }^{\circ} \mathrm{C}$ for $3 \mathrm{C}$ discharge at $25{ }^{\circ} \mathrm{C}$ and 9 ${ }^{\circ} \mathrm{C}$ for $6 \mathrm{C}$ discharge at $0{ }^{\circ} \mathrm{C}$. For a 18650-type cell at $25{ }^{\circ} \mathrm{C}$ and continuous-discharge, the temperature difference between the jelly and the surface $\left(\Delta \mathrm{T}_{\text {jelly }}\right)$ was $5.0^{\circ} \mathrm{C}$ for $1 \mathrm{C}, 8{ }^{\circ} \mathrm{C}$ for $2 \mathrm{C}$ and $18{ }^{\circ} \mathrm{C}$ for $5 \mathrm{C}$ as observed by Waldmann et al. [15]. The $\Delta \mathrm{T}$ obtained in this paper for different operating conditions is slightly overstated as compared to [14] who only investigate temperature gradients on the surface, but is more in agreement with [15] who compared internal and surface temperatures. This follows that internal temperature estimated in this paper is representative of the average bulk temperature of cell while measured temperatures are obtained from sensor/thermocouple readings on the cell's surface.

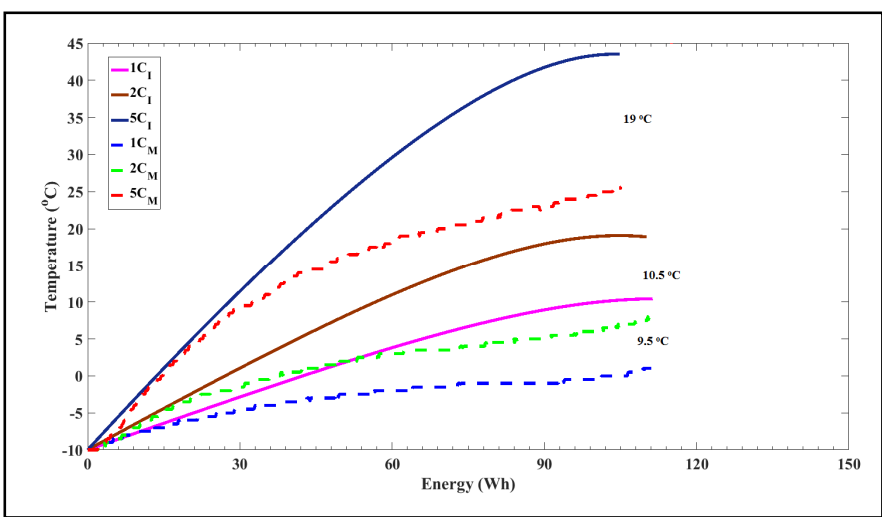

Fig. 7. Comparison between Internal (I) and Measured (M) Temperatures for Various C-rates at $25^{\circ} \mathrm{C}$ Ambient Temperature

Lastly, it is seen that, the difference between the cell's internal and measured temperatures generally increases as discharge progresses; peaks towards the middle of discharge (Fig. 8) and reduces towards the end of discharge. The magnitude of this difference increases with C-rate and ambient temperature. 


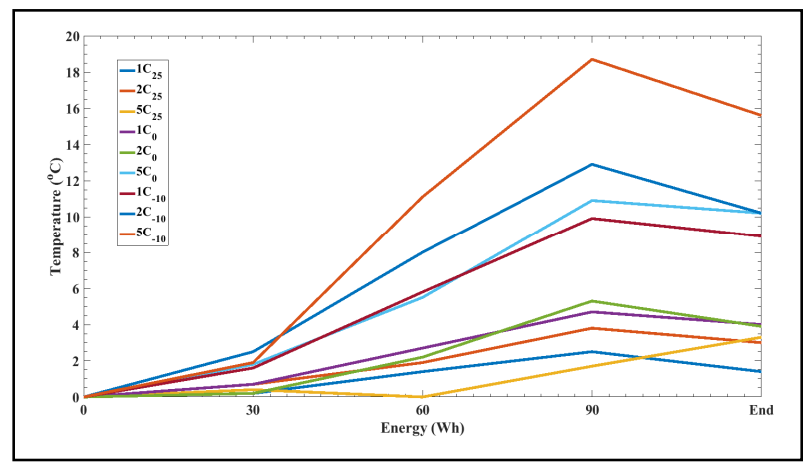

Fig. 8. Evolution of Difference between Internal and Measured Cell Temperatures for every $30 \mathrm{Wh}$ Discharge

\section{CONCLUSIONS}

- At lower ambient temperatures, capacity benefits attributed to self-heating are overstated and may not translate into improvement in energy available from the cell.

- Effective resistance of the cell is greater for higher discharge-current and lower ambient temperature.

- The difference between internal and measured cell temperatures, increases with increasing dischargecurrent and declining ambient temperature.

- Over a discharge-cycle, the difference between internal and measured cell temperatures, rises at the beginning of discharge, before peaking in the middle region and reducing towards the end of discharge.

\section{FURTHER WORK}

Based on the above results, the thermal conductivity of the cell for various subzero ambient temperatures and heat-generation rates can be estimated. The accuracy of the technique presented can be tested against temperature predicted from a heat-generation model as part of an equivalent circuit-model for this particular Lithium-ion pouch cell. Effects of lower ambient temperatures and higher $\mathrm{C}$-rates can be considered via magnitude of time-step in the internal temperature prediction. Finally, the accuracy of this technique can be compared against data obtained from in situ temperature measurements of the cell.

\section{ACKNOWLEDGMENT}

The research presented within this paper is supported by Innovate UK through the WMG centre High Value Manufacturing (HVM) Catapult in collaboration with Jaguar Land Rover and TATA Motors European Technical Centre.

\section{REFERENCES}

C.C. Chan, The state of the art of electric, hybrid, and fuel cell vehicles, Proc. IEEE. 95 (2007) 704-718. doi:10.1109/JPROC.2007.892489.

[2] P. Miller, Automotive Lithium-ion Batteries, Johnson Matthey Technol. Rev. 59 (2015) 4-13. doi:10.1595/205651315X685445.

[3] J.M. Miller, Energy storage system technology challenges facing strong hybrid, plug-in and battery electric vehicles, 2009 IEEE Vehicles Power Propulsion Conference (2009) 4-10. doi:10.1109/VPPC.2009.5289879.

[4] F. V. Conte, Battery and battery management for hybrid electric vehicles: A review, Elektrotechnik Und Informationstechnik. 123 (2006) 424-431. doi:10.1007/s00502-006-0383-6.

[5] S.A.H. Zahabi, L. Miranda-Moreno, P. Barla, B. Vincent, Fuel economy of hybrid-electric versus conventional gasoline vehicles in real-world conditions: A case study of cold cities in Quebec, Canada, Transp. Res. Part D Transp. Environ. 32 (2014) 184-192. doi:10.1016/j.trd.2014.07.007.

[6] P. Keil, M. Englberger, A. Jossen, Hybrid Energy Storage Systems for Electric Vehicles: An Experimental Analysis of Performance Improvements at Subzero Temperatures, IEEE Trans. Veh. Technol. 65 (2016) 998-1006. doi:10.1109/tvt.2015.2486040.

[7] Q. Wang, B. Jiang, B. Li, Y. Yan, A critical review of thermal management models and solutions of lithium-ion batteries for the development of pure electric vehicles, Renew. Sustain. Energy Rev. 64 (2016) 106-128. doi:10.1016/j.rser.2016.05.033.

[8] Y. Ji, Y. Zhang, C.-Y. Wang, Li-Ion Cell Operation at Low Temperatures, J. Electrochem. Soc. 160 (2013) A636-A649. doi:10.1149/2.047304jes.

[9] S. Goutam, J.M. Timmermans, N. Omar, P. Van den Bossche, J. Van Mierlo, Comparative study of surface temperature behavior of commercial li-ion pouch cells of different chemistries and capacities by infrared thermography, Energies. 8 (2015) 8175-8192. doi:10.3390/en8088175.

[10] B. Wu, Z. Li, J. Zhang, Thermal Design for the Pouch-Type LargeFormat Lithium-Ion Batteries: I. Thermo-Electrical Modeling and Origins of Temperature Non-Uniformity, J. Electrochem. Soc. 162 (2014) A181-A191. doi:10.1149/2.0831501jes.

[11] W. Waag, C. Fleischer, D. Uwe, Critical review of the methods for monitoring of lithium-ion batteries in electric and hybrid vehicles, $\mathrm{J}$. Power Sources. 258 (2014).

[12] G. Liu, M. Ouyang, L. Lu, J. Li, X. Han, Online estimation of lithium-ion battery remaining discharge capacity through differential voltage analysis, J. Power Sources. 274 (2015) 971-989. doi:10.1016/j.jpowsour.2014.10.132.

[13] M. Berecibar, F. Devriendt, M. Dubarry, I. Villarreal, N. Omar, W. Verbeke, J. Van Mierlo, Online state of health estimation on NMC cells based on predictive analytics, J. Power Sources. 320 (2016) 239-250. doi:10.1016/j.jpowsour.2016.04.109.

[14] C. Veth, D. Dragicevic, C. Merten, Thermal characterizations of a large-format lithium ion cell focused on high current discharges, J. $\begin{array}{lllll}\text { Power } & \text { Sources. } & 267 & \text { (2014) }\end{array}$ doi:10.1016/j.jpowsour.2014.05.139.

[15] T. Waldmann, M. Wohlfahrt-Mehrens, In-Operando Measurement of Temperature Gradients in Cylindrical Lithium-Ion Cells during High-Current Discharge, ECS Electrochem. Lett. 4 (2015) A1-A3. doi:10.1149/2.0031501eel.

[16] J. Jaguemont, L. Boulon, Y. Dube, Characterization and Modeling of a Hybrid-Electric-Vehicle Lithium-Ion Battery Pack at Low Temperatures, IEEE Trans. Veh. Technol. 65 (2016) 1-14. doi:10.1109/TVT.2015.2391053.

[17] T.F. Fuller, M. Doyle, J. Newman, Simulation and Optimization of the Dual Lithium Ion Insertion Cell, J. Electrochem. Soc. 141 (1994) 1. doi:10.1149/1.2054684.

[18] W. Waag, S. Käbitz, D.U. Sauer, Experimental investigation of the lithium-ion battery impedance characteristic at various conditions and aging states and its influence on the application, Appl. Energy. 102 (2013) 885-897. doi:10.1016/j.apenergy.2012.09.030.

[19] K.A. Smith, Electrochemical Control of Lithium-Ion Batteries, (2010).

[20] A. Barai, G.H. Chouchelamane, Y. Guo, A. McGordon, P. Jennings, A study on the impact of lithium-ion cell relaxation on electrochemical impedance spectroscopy, J. Power Sources. 280 (2015) 74-80. doi:10.1016/j.jpowsour.2015.01.097. 